\title{
A várakozások szerepe a közgazdasági gondolkodásban
}

A tanulmány európai országok aktuális gazdaságpolitikai problémáiból kiindulva arra keres választ, hogy a közgazdasági elméletek hogyan kezelik a várakozásokat. A klasszikus közgazdaságtan érdektelensége után az 1930-as évektől a dinamikus makroelemzésekben már nagy figyelem irányult a vizsgálatukra. A várakozásokat az 1940-es évektől építették be formalizált modellekbe. A neoklasszikus alapokra épüilö közgazdasági logikába következetesen az újklasszikus makroökonómia illesztette be. A tanulmány arra a következtetésre jut, hogy a közgazdaságtan gazdaságpolitikai jelentőségük ellenére sosem vonta vizsgálati körébe azokat a közgazdasági szempontból nem racionális várakozásokat, amelyek nem átmeneti külső sokként jelentkeznek, hanem a gazdaság társadalmi beágyazottságából adódnak. Ilyen eseteket a politikai gazdaság eszköztárával lehet megközelíteni.*

Journal of Economic Literatur (JEL) kód: A13, B41, E32.

Az Európai Unió gazdaságainak intézményi összehasonlítása során szembetünő, hogy egyes országoknak a gazdasági teljesítménye rosszabb eredményeket mutat, mint amit a gazdasági és pénzügyi folyamatok önmagukban indokolnának. Négy ország esetében nyilvánvaló, hogy az utóbbi egy-két évtizedben a társadalom önértékelése, a társadalmi várakozások hátrányosan hatottak a gazdaság teljesítményére. Franciaországban a fél szívvel végrehajtott reformok sora mögött a hiányzó társadalmi támogatás, a társadalom tetemes hányadának gazdaságpolitikai várakozásai állnak, amelyek a jóléti állam fénykorának megfelelő újraelosztást igénylik. A nagy belső piac és a háború utáni évtizedekben elért magas fejlettségi szint több mozgásteret ad Franciaországnak, mint a kis, nyitott gazdaságoknak, a német gazdasággal összehasonlítva azonban egyértelmü a lemaradás.

Olaszország egy före jutó GDP-je az elmúlt évtizedben 16 százalékponttal csökkent vásárlóerő-paritáson az uniós átlaghoz képest. Ennek ellenére a szakértői Monti-

* A tanulmány a TÁMOP-4.2.1.D-15/1/KONV-2015-0002 azonosító számú, Tudásipar igényeit kiszolgáló felsőoktatási szolgáltatások megalapozása a Dél-Alföldi régióban címü pályázat keretében készült.

Farkas Beáta egyetemi tanár, SZTE Pénzügyek és Nemzetközi Gazdaság Kapcsolatok Intézete. A kézirat első változata 2016. május 23-án érkezett szerkesztőségünkbe.

DOI: http://dx.doi.org/10.18414/KSZ.2016.11.1177 
kormány 2011-2112-es kérészéletű kormányzása világosan mutatta, hogy a társadalom többsége elutasítja a fájdalmas pirulákat, amelyeket be kellene vennie ahhoz, hogy visszanyerje régi gazdasági erejét.

Görögországban a végrehajtandó korrekciók elodázása, elszabotálása olyan spirálba vitte a gazdaságot, hogy a 2008-as válság előtt az uniós átlaghoz közeli egy főre jutó, vásárlóerő-paritáson mért GDP 2014-re 73 százalékosra zsugorodott.

Magyarországon a jóléti várakozásokat politikai csatákban kihasználó kormányok nemcsak látványos választási ciklusokat hoztak létre a költségvetési deficit alakulásában, hanem az ország a régió egyik élenjáró gazdaságából a sereghajtók közé került. A jövő mutatja meg, hogy az utóbbi évek stabilabb államháztartása tartós elszakadást jelent-e a „fiskális alkoholizmus” gyakorlatától.

Ezek a megfigyelések vetették fel a kérdést, hogy a közgazdasági elméletek hogyan kezelik a gazdasági folyamatokat befolyásoló várakozásokat, mennyiben veszik figyelembe a várakozások társadalmi formálódását. ${ }^{1}$

\section{A klasszikusok mechanikus világa}

Nagyon régi az a felismerés, hogy a gazdasági tevékenységben, döntéshozatalban a jelen és a bizonytalan jövő között a várakozások teremtenek kapcsolatot, és ennek nagy jelentősége lehet a gazdálkodás eredményességében. Már Arisztotelész lejegyezte a következö történetet Thalészról:

„....kiszámította, mint mondják, csillagászati úton, hogy bő olajtermés lesz, s bár kevés pénzzel rendelkezett, még a télen valamennyi milétoszi és khioszi olajsajtolóra foglalót adott, s olcsón kibérelte őket, mivel senki sem ígért többet; mikor aztán elérkezett az olajsajtolás ideje, egyszerre és hirtelen nagy kereslet támadt, s ekkor ő olyan áron adta az övéit bérbe, ahogy akarta..." (Arisztotelész [1984] 11. o.).

Hasonló utalásokat szemezgethetnénk a premodern kor filozófus, teológus vagy éppen irodalmár szerzőitől, de a közgazdaságtan mint önálló diszciplína megjelenésekor, azaz a klasszikus politikai gazdaságtanban a várakozások szerepével közvetlenül alig foglalkoztak. Arra, hogy mit feltételeztek a gazdasági szereplők döntéshozataláról, milyen várakozásokat tulajdonítottak nekik, közvetve tudunk következtetni egyes nézeteikből, valamint az általuk használt emberképből.

A klasszikus politikai gazdaságtan szerzőire, legelsőként Adam Smithre mély hatást gyakorolt a newtoni mechanika. Abból az elképzelésböl indultak ki, hogy a gazdaságban éppúgy létrejöhet egy harmonikus, egyensúlyi állapot, mint a bolygók mozgásában. A newtoni mechanika világképe Smithnél összeépült a természeti törvény feltételezésével, egyfajta természetjogi gondolkodással. Ennek jegyében etikája és közgazdaságtana is arra a feltételezésre épült, hogy az isteni gondviselés úgy rendezte el a világot, hogy a természetes rend törvényeit követve az emberiség boldogsága megvalósuljon. Nem meglepő, hogy az egyes gazdasági szereplők várakozásának

\footnotetext{
${ }^{1}$ A témáról bővebben lásd Farkas [2016].
} 
nem maradt jelentősége, hiszen a „láthatatlan kéz” létrehozza az önérdekkövetés és az együttérzés ellentétes erőiből az egyének autonóm cselekedetein keresztül a társadalmi rendet (Smith [1940], [1977]).

David Ricardo absztrakt modelljeiben minden különösebb magyarázkodás nélkül, mintegy evidenciaként használta az önérdekkövető, haszonmaximalizáló gazdasági szereplő feltételezését. Elfogadta az általános túltermelés lehetetlenségét megfogalmazó Say-törvényt, azaz elutasította annak a lehetőségét, hogy tartós zavarok állhatnak be a szabad versenyes kapitalizmus müködésében, ami közvetve azt is jelenti, hogy a racionális, haszonmaximalizáló szereplök várakozásai sem okozhatnak fennakadást (Ricardo [1991]).

Thomas R. Malthus szintén nem foglalkozott a várakozásokkal. Ö ugyan megkérdőjelezte a Say-törvényt, azonban csak olyan jelenségre figyelmeztetett, amely beleillik a homo oeconomicus képébe, és független a várakozásoktól. Malthus ugyanis nem tekintette automatikus folyamatnak, hogy a megtakarítások-beruházások bővülését elégséges fogyasztás kísérje (Ricardo [1969]).

John Stuart Mill elgondolásai egyfajta kettősséget mutatnak. Minden elődjénél tudatosabban épített a haszonelvüségre, és az utilitarizmushoz mint filozófiai irányzathoz is jelentős a hozzájárulása. Kifejezetten vállalta, hogy egy nem valóságos, leegyszerüsített emberképet használ, a racionális haszonmaximalizáló homo oeconomicust. Ugyanakkor számolt azzal, hogy pszichológiai tényezőknek köszönhetően válság állhat elö. Mill a Say-törvényt elfogadta, ha naturális cserekereskedelem folyik, amikor egy terméket egy másikra cserélnek, valamint ha a pénz csak csereeszközként funkcionál. Ha azonban a pénz az értékfelhalmozás eszköze is, akkor az eladás és a vásárlás elválhat egymástól. Egy fellendülés, nagymértékủ hitelbővülés, spekulatív vásárlások és gyors áremelkedés után megrendülhet a gazdaságban a bizalom, mindenki inkább tartani akarja a készpénzt. Tehát nem túltermelés áll elö, hanem a pszichológiai okból megváltozott várakozások miatt rövid ideig átmeneti túlkínálat alakul ki. Olyan krónikus stagnálás, mint amire Malthus utalt, Mill szerint nem következhet be (Mill [1874-1875]).

A várakozásoknak Henry Thorton tulajdonított kifejezett jelentőséget. Az elmélettörténeti munkákban szembe szokták állítani Ricardo hosszú távú egyensúlyra összpontosító, az aranyfedezethez mereven ragaszkodó pénzelméletét Henry Thorton árnyaltabb, a monetáris politika rövid távú hatásaival is számoló elméletével. Ez a különbség abban is megmutatkozik, hogy Thorton An Enquiry into the Nature and Effects of the Paper Credit of Great Britain címü legnevezetesebb könyvében a pénzügyi és gazdasági folyamatok magyarázatában többszörösen felhasználta a várakozások szerepét. A várakozások többféle gazdasági jelenségre vonatkoznak, például a kincstárjegy kínálatára, a pénzmennyiség változására, a valuta árfolyamára, a gazdasági kilábalás hosszára. Egyes esetekben a várakozások Thortonnál nemcsak a jövő alakulását befolyásolják, hanem a jelenre is visszahatnak, és kapcsolatban vannak a bizalommal, a félelmekkel, utóbbiak szerinte a bankokkal szemben vetödnek fel (Thornton [1965]).

Összességében azonban a klasszikusok statikus egyensúlyi állapotok sorozatát vizsgálták, a miben a gazdasági szereplök előrelátásának, várakozásainak nem volt érdemleges jelentőségük. 


\section{A neoklasszikus ortodoxia a várakozásokról}

A neoklasszikusok előfutárai, a marginalisták még mindig a fizika, azon belül a mechanika megközelítését követték. Mind Stanley Jevons, mind Léon Walras rámutatott arra, hogy a közgazdaságtan analógiát mutat a fizikával. Jevons a közgazdaságtant a statikus mechanikához hasonlította, Walras a tiszta, azaz elméleti közgazdaságtant fizikai-matematikai tudományként definiálta. Ebből már logikus módon adódott, hogy a várakozásoknak nem szenteltek figyelmet.

A neoklasszikus paradigma atyjának tekintett Alfred Marshall egyik fö törekvése az volt, hogy a közgazdasági elméletet közelebb vigye a valósághoz. Ennek során bekapcsolta az elemzéseibe az időtényezőt, megkülönböztette a hosszú és rövid távú gazdasági hatásokat. Az ármeghatározás esetében különböző időperiódusokat különített el, amelyekben a kínálati oldal eltérően alkalmazkodik a kereslethez. Rámutatott arra, hogy az a stabil, stacionárius egyensúlyi állapot, amelyben a klasszikusok gondolkodtak, nagyon valószerütlen feltételezések mellett áll fenn, $\mathrm{s}$ már a saját korát is a gyors változások koraként érzékelte. Smith és más klasszikusok a normál vagy „természetes” értéket olyannak tekintették, amelyet a gazdasági erők hosszú távon hoznak létre. Ez egy olyan átlagérték lenne, amely akkor jöhetne létre, ha az élet általános feltételei változatlanok, stacionáriusak lennének. Marshall kifejtette azonban, hogy a jövőt nem láthatjuk tökéletesen előre, a meglevő tendenciák már az előtt módosulhatnak, mielőtt teljesen kifejthetnék hatásukat. Ebben a változó világban az áralakulás magyarázatához Marshallnak szüksége volt a várakozások fogalmának bevezetésére. A jelenbeli kínálat ugyanis olyan döntések eredménye, amely a jövőbeli áralakulásra, keresletre vonatkozó várakozások alapján születtek meg (Marshall [1997]).

Marshall kortársa, Knut Wicksell svéd közgazdász munkássága legnagyobb hatást a pénzelméletre gyakorolt, amely összekapcsolódott a gazdasági ciklusok magyarázatával és a jövedelemelosztás elméletével. A századforduló körül írt legfontosabb írásai elöször a saját hazájában sem keltettek visszhangot. A harmincas évek közepéig csak németül voltak elérhetők, az angol fordítások ezután jelentek meg. Pályája késői éveiben viszont már a svéd közgazdasági élet egyik szaktekintélye lett. A lundi egyetem nyugdíjas professzoraként Stockholmban egyengette azoknak a fiataloknak az útját, akik a „stockholmi iskola" meghatározó személyiségeivé váltak, és amely iskola eredményei témánk szempontjából jelentősek (Madarász [2000] 428. o.)

Wicksell a ricardói mennyiségi pénzelméletet tekintette az egyetlen tudományos pénzelméletnek, amely azonban számos ellenvetésnek hagyott teret. A mennyiségi pénzelmélet egyik állítása, hogy a pénz mennyiségének növekedése egyrészt az árak növekedéséhez, másrészt a kamatlábak csökkenéséhez vezet. Az alacsony kamatlábakat hitelbővülés kíséri, és a kölcsönvevők felhajtják az árakat, amikor az új pénzügyi forrásaikat felhasználják. Számos megfigyelés azonban azt mutatta, hogy gyakoribb eset, amikor a növekvő árakat magas vagy növekvő kamatláb kísérte, és megfordítva: a csökkenő árakat csökkenő kamatláb. Wicksell ennek a magyarázatát abban találta meg, hogy a piaci - a bank számára fizetendő - kamatláb mellett figyelembe vette a tőke természetes kamatlábát. Ez utóbbi pedig nem más, mint az újonnan előállított 
tőke várt hozadéka. Az, hogy a piaci kamatláb mikor alacsony vagy magas, az a természetes kamatlábhoz való viszonyától függ. Ha a két ráta eltér, például ha a piaci kamatláb alacsonyabb, mint a természetes, akkor a kedvező profitkilátások miatt élénkül a kereslet. A termelök ugyan többet fizetnek a nyersanyagokért, bérekért, bérleti dijért stb., de termékeikért is magasabb árat kapnak. Ha a hitelintézetek tartósan fenntartják az alacsony kamatot, egy kumulatív folyamat indul be (Wicksell [1936]). Wicksell azzal, hogy a pénzmennyiség változását összekapcsolta a vállalkozók döntéseivel, felhasználva a várakozások szerepét, új meglátások felé nyitott utat a gazdasági ciklusok elemzésében, amelyeket később a stockholmi iskolában használtak ki.

Marshall és Wicksell generációjához kapcsolódott Irving Fisher, aki az Egyesült Államokban 1907-ben jelentkezett kamatelméletével, amelyben figyelembe vette a várakozások szerepét. Szerinte a kamatlábakat két erő befolyásolja. Egyfelől a gazdasági szereplők preferenciái, amelyek azt fejezik ki, hogy a jelenbeli javakat vagy jövedelmet mennyire részesítik előnyben a jövőbeliekkel szemben. Másfelől a beruházási lehetőségek, amelyek meghatározzák az elérhető hozamot. Kamatelméletét több logikai lépésben fejtette ki, elöször rugalmatlan jövedelmeket feltételezett, utána rugalmasakat, és végül figyelembe vette a jövedelmek bizonytalanságát. Az intertemporális döntéseket vizsgálva a várakozások mindhárom esetben szerepet kaptak, de az utolsó, leginkább valóságközeli helyzetben igazán jelentősek, hiszen a kockázat következménye, hogy a beruházások után ténylegesen realizált hozam rátája messze eltérhet a várt rátától (Fisher [1907] 212. o.). Kamatelméletét 1930-ban kiadott könyvében fejlesztette tovább, amivel az adaptív várakozások gondolata elöfutárának tekinthető (Fisher [1930]). Arra a meglátására, hogy a jelenbeli fogyasztás a jövőbeli jövedelmi kilátásoktól is függ, a későbbiekben Friedman épített a permanens jövedelemelméletében.

Marshall utódja a cambridge-i egyetemen Arthur Cecil Pigou volt, aki mesteréhez hasonlóan elkötelezte magát a gyakorlati élet problémáihoz közel álló közgazdaságtan mellett. A várakozások szerepe munkásságának több területén megjelent. Az gazdasági ciklusokat Pigou azzal magyarázta, hogy a gazdaságot reál-, pszichológiai vagy monetáris impulzus éri. A reálimpulzus sokféle lehet, a termés jövedelemének megváltozásától egy nyersanyag-lelőhely felfedezésén át a hazai vagy a külföldi kereslet megváltozásáig. Pszichológiai impulzus származhat például egy korlátozott információn alapuló téves elörejelzésen, amely az üzleti kapcsolaton keresztül általánosan elfogadottá válik, és nyájszerü viselkedéshez vezethet. Az aranystandard korában monetáris impulzus csak bányafelfedezésből vagy külső pénzügyi változásokból eredhet. Pigou szerint azonban minden impulzus csak akkor vált ki gazdasági ciklust, ha érinti az üzletemberek várakozását (lásd Collard [1996] 914. o.). Pigou fö müvében, a The Economics of Welfare-ben nem kevésbé jelentős a várakozások szerepe. A nem szabadpiaci bérszabályozás elemzésében éppúgy felhasználta a várakozások fogalmát, mint annak a magyarázatában, hogy milyen hatást gyakorol a nemzeti jövedelemre, ha a gazdagoktól jövedelmet csoportosítanak át a szegényekhez. Utóbbi kapcsán kifejezetten megfogalmazta, hogy az átcsoportosítás különböző feltételeinek hatását úgy lehet a leghatékonyabban vizsgálni, ha szétválasztjuk a tények hatását és a várakozások hatását (Pigou [1932] 402. o.). 


\section{A dinamikus makroelemzések az 1930-as években}

A várakozások fogalmának elemzése az 1930-as években a dinamikus makroelemzésekkel indult el igazán. A kor jelentős közgazdászainak figyelme - legyen szó akár a stockholmi iskoláról, az osztrák iskolából induló, de ekkor már Londonban müködő Hayekröl, Hicksről, Keynesröl - a gazdasági ciklusok magyarázata felé fordult, amelyben a várakozásoknak kiemelkedő szerepet tulajdonítottak. Ezt az érdeklődést kézen fekvően tulajdoníthatjuk az 1929-1933-as világválság hatásának. Hicks [1965] (58-59. o.) azonban rámutatott, hogy már ezt megelőzően, az 1914 elötti nemzetközi aranystandardrendszer összeomlásával a pénzelméletben olyan kérdések merültek fel, amelyeket dinamikus kérdéseknek nevezett, és amelyek statikus módon nem válaszolhatók meg, például kérdésessé vált, hogyan érhető el a pénzügyi stabilitás, az árstabilitás.

A stockholmi iskola Wicksell pénzelméletére épített az 1920-1930-as években, és ennek során központi jelentősége volt a Gunnar Myrdal által bevezetett, azóta is jól ismert ex ante és az ex post kalkulációk megkülönböztetésnek. Myrdal a wickselli kumulatív folyamatot úgy értelmezte, hogy a beruházások előzetesen feltételezett, ex ante értéke eltért az ex post mért reálértékétől. A megtakarítások, beruházások és az árszínvonal-változás kapcsolatának elemzésében az iskola más tagjai is felhasználták, továbbfejlesztették az ex ante-ex post megközelítést. Itt most csak Eric Lindahlra térek ki, mert közvetlen kapcsolatban állt Hicksszel, aki maga is hivatkozott Lindahl rá gyakorolt hatására (Hicks [1965]). Lindahl a statikus elemzés lényegét úgy fogalmazta meg, hogy a gazdasági jelenségek itt is időben zajlanak, csak a tanulmányozott változók értéke időben nem módosul. Azokat a közösségeket, ahol ugyanazok a folyamatok ismétlődnek, stacionárius közösségnek nevezzük. Ez az egyszerü megoldás azonban nem elégséges a valóságos, változó és fejlődő világ problémáinak feltárásához, ehhez statikus helyett dinamikus elméletre van szükség. A dinamikus folyamatok megragadása nála is magával hozta a várakozások bevonását az elemzésbe, amihez átvette az ex ante-ex post kalkuláció megkülönböztetését. A gazdasági szereplők viselkedését a tervezés alapozza meg, ami maga is időben változó, a szereplök felülvizsgálják a terveiket. Lindahl nem feltételezte, hogy a szereplők viselkedése leírható a racionális, haszonmaximalizáló magatartással. A tervezés szerinte magában foglalja egyrészt az előrevetítést (anticipation), másrészt az értékelést. Utóbbi során a gazdasági szereplő az előnyösség (advantageousness) mértéke szerint dönt, aminek a mércéjét a saját egyéni értékelési attitüdje írja elő. Mindkét mozzanat idővel változhat, de az értékelési attitüd megváltozása általában rendszertelen és elméletileg nehezen kezelhetö (Lindahl [1970] 31-32., 40-43., 47. o.).

A stockholmi iskola mellett az osztrák iskolában is felbukkant a várakozások vizsgálata. Eugen von Böhm-Bawerk nem foglalkozott gazdasági ciklusokkal, de tőkeelmélete a termelési kerülőút gondolatára épült, vagyis magában foglalta az időbeliséget. Kamatelmélete hatott Wicksellre és az osztrák iskolán belül Ludwig von Misesre, aki - különösen munkássága későbbi szakaszában - felhasználta a várakozásokat a gazdasági ciklusok magyarázatában (Festré [2006]). Az osztrák iskola tagjai közül Friedrich August von Hayek hozzájárulása volt jelentős témánkhoz. Saját cikluselméletéhez mélyebben 
megvizsgálta azokat a megismeréssel kapcsolatok feltételezéseket, amelyek mellett a neoklasszikus egyensúlyelmélet fenntartható. Hayek kiindulópontja az volt, hogy az egyensúly egyszerüen értelmezhető, ha egy elszigetelt egyén cselekedetét vizsgáljuk. Akkor és addig beszélhetünk egyensúlyról, amíg az egyénnek a cselekvési tervét nem kell módosítania, mert az elörelátása (foresight), elörevetítése (anticipation) helyesnek bizonyul. A valóságban azonban a gazdasági szereplők a terveket szimultán és egymástól függetlenül határozzák meg. Az egyensúly akkor valósul meg, ha minden szereplö terve azokat a cselekvéseket várja, amelyeket mások szándékoznak megvalósítani, és mindenkinek a várakozása ugyanazokra a külső tényekre épül. A helyes előrelátás nem elöfeltétele az egyensúlynak, hanem az addig áll fenn, amíg az elörelátás helyesnek bizonyul. Hayek azt kritizálta, hogy az egyensúlyelméletek nem azt magyarázzák meg, hogy miként jön létre az egyensúlyi állapot, hanem magát a problémát iktatják ki annak a feltételezésével, hogy a szereplők számára a döntéseikhez szükséges releváns információk automatikusan rendelkezésre állnak. Ahogy roppant ironikusan fogalmazott, „a csontváz a szekrényből, a »gazdasági ember«, akit imával és böjtöléssel kifüstöltünk, a hátsó ajtón visszatért egy kvázimindentudó egyén formájában" (Hayek [1937] 45. o.). ${ }^{2}$ Szerinte a tudásmegosztás, a társadalmi tanulási folyamat tanulmányozásával kerülhetnénk közelebb a valóságos világ megértéséhez.

John Maynard Keynes fő müvében a gazdasági jelenségeket a várakozások figyelembevételével magyarázta. A gazdálkodás természetéből következik, hogy az ember döntéseihez kénytelen várakozásokat alapul venni, ha termelni akar olyan folyamatok segítségével, amelyek időt igényelnek. Különbséget tett rövid és hosszú távú várakozások között. Rövid távon a vállalat a bevételekre és a költségekre vonatkozó várakozások függvényében dönt a napi termelés nagyságáról. A „napi” itt nem a szó szoros értelmében 24 órát jelent, hanem azt a legrövidebb időtávot, amelyen belül a foglalkoztatás nagysága nem változtatható. A jelenbeli döntéseket a jelenbeli várakozások határozzák meg, a múltbeli várakozások - amelynek a hatásai még ki sem bontakozhattak - csak annyiban befolyásolják a jelenbeli döntéseket, amennyiben a tökefelszerelésben testet öltenek. A várakozások kiterjednek mind a reál-, mind a pénzfolyamatokra, ezek össze is fonódnak egymással, de a kulcsfogalom a töke határhatékonysága. A beruházások nagysága részben ez utóbbitól függ, a tőke határhatékonysága viszont a tőketárgy kínálati ára és a várható hozama közötti viszony függvénye. A hosszú távú várakozások olyan tényezőkre irányulnak (például a hatékony kereslet nagyságára a beruházás élettartama alatt, a fogyasztók ízlésének, illetve a nominális béregységeknek a változására), amelyek a várható hozamot, ezáltal a tőke határhatékonyságát befolyásolják.

A ciklusok magyarázatánál Keynes vitába szállt azzal a nézettel, hogy egy válság kitörésében a növekvő pénzkereslet nyomán növekvő kamatláb játszana meghatározó szerepet. Azt állította, „hogy a válság tipikusabb és gyakran domináló oka elsődlegesen nem a kamatláb emelkedése, hanem a tőke határhatékonyságának a hirtelen összeomlása" (Keynes [1965] 340. o.). A fellendülés szakaszában a majdani hozamra vonatkozó várakozások optimisták. Amennyiben egy idő után a beruházási piac túl

\footnotetext{
${ }^{2}$ A magyar fordításból az ironikus teológiai utalás nem derül ki olyan egyértelműen, mint az angol cikkből, az exorcise ige az ördögűzést jelenti, ominscient (mindentudás) pedig isteni tulajdonság.
} 
optimista, hirtelen kétségek merülnek fel a várt hozamok megtérülésével kapcsolatban, és az illúziók elillannak, a csapás hirtelen és katasztrofális jellegü. A tőke határhatékonyságának összeomlását a likviditási igény rohamos fokozódása kíséri, ami megemeli a kamatlábat. A várakozások alakulásával kapcsolatban Keynes többször hivatkozott pszichológiai tényezőkre, szerinte a bizalom a töke határhatékonyságára éppúgy hat, mint a kamatlábra. Ezért a válság után „nem könnyü újra életre kelteni a tőke határhatékonyságát, mert az az üzleti világ ellenőrizhetetlen és makacskodó lelkiállapotától függ" (uo. 341-342. o.). Ennek ellenére Keynes nem gondolta, hogy a várakozások irracionális lélektani állapotoktól függenek. A döntések ugyanakkor „nem lehetnek szigorú matematikai remény függvényei, mert nincs alap ilyen kalkulációk elvégzéséhez”... az ember „kalkulál ott, ahol képes rá, de a mozgatóerők gyakran nem egyebek, mint a szeszély, érzelem vagy véletlen" (uo. 184. o.). Keynes az Általános elméletben beszélt arról, hogy a beruházás tényleges eredményei nagyon ritkán egyeznek meg az eredeti várakozásokkal (uo. 174. o.), ami eszünkbe juttatja a stockholmi iskola ex ante-ex post megkülönböztetését. Maga Keynes is ismerte a stockholmi iskola eredményeit, föként miután az angol fordítások megjelentek, de csak ígéret maradt, hogy egy tanulmányban reflektál az ex ante-ex post elemzés és a saját elmélete viszonyáról (Meacci [2012]).

A korszak föszereplőinek áttekintését John Richard Hicksszel zárjuk. A stockholmi iskolához füződő kapcsolatáról már esett szó, de arról is ő maga számolt be, hogy a London School of Economicson többek között Hayekkel folytatott szakmai konzultációkat, majd arról is vallott, hogy a tőkeelmélet tanulmányozásakor kitüzött céljában - egy új dinamikus elmélet létrehozásában - Keynes megelőzte őt (Hicks [1978]). Az Érték és tőke 1939-ben megjelent munkájának kiindulópontja is az, hogy ha a statikus elemzést dinamikussal váltjuk fel, akkor számolnunk kell a várakozásokkal. Az árvárakozásokat szerinte háromféle tényező befolyásolja. Egyrészt a gazdaságon kívüli tényezők, például az időjárás, a politikai események, az emberek egészségi állapota és pszichológiája. Másrészt gazdasági jellegüek, amelyek azonban nem kapcsolódnak közvetlenül az ármozgáshoz. Ezek éppúgy lehetnek jövőre vonatkozó termelési hírek, mint piaci babonák. Harmadrészt az árakra vonatkozó múltbeli és jelenlegi valóságos tapasztalatok. Hicks megállapította, hogy az első két tényezővel nem tudunk mit kezdeni, független változók ként kell kezelni őket. Tudományos vizsgálat tárgya a harmadik lehet. Ehhez bevezette a várakozások rugalmasságának fogalmát, amin azt értette, hogy milyen arány áll fenn $X$ áru jövőbeli árának várt százalékos növekedése és $X$ áru jelenbeli árának növekedése között. Ha a várakozások tökéletesen rugalmatlanok, azaz nullával egyenlők, akkor minden jelenbeli árváltozást átmenetinek tekintenek. Ha a várakozások értéke egy, akkor a várt árváltozások iránya és mértéke megegyezik a jelenbeliekével. A várakozások rugalmassága nemcsak nulla és egy közé eshet, de egynél nagyobb és negatív is lehet. „A várakozások rugalmassága akkor nagyobb egynél, ha a jelenbeli árak változása azt az érzést kelti az emberekben, hogy egy tendenciát ismertek fel, s ennélfogva megkísérlik azt extrapolálni. Negatív lesz a várakozások rugalmassága akkor, ha az embereknek az előbbivel ellentétes típusú sejtéseik vannak, ha tehát az áringadozás tetőpontjaként értelmezik a változást." (Hicks [1978] 241. o.) Hicks nem hozott létre kvantitatív várakozáselméletet, de a várakozások 
rugalmasságának fogalma már ebbe az irányba mutat, és az extrapolatív, illetve az adaptív várakozások alapgondolatát is megtaláljuk nála.

Az 1930 -as években a korszak meghatározó gondolkodóinál megtalálható néhány közös elem, függetlenül attól, hogyan viszonyultak a neoklasszikus paradigmához. A dinamikus elemzést még mindig a stacionárius állapothoz viszonyítva építették fel. Ennek elkerülhetetlenül figyelembe vett tényezői közé tartoznak a várakozások. Hayek kivételével minden idézett szerző kifejezetten megfogalmazta, hogy a várakozásokat meghatározó okok közül nem mindegyik ragadható meg a közgazdasági elemzés eszközeivel. Azonban más tudományterület illetékességi körébe sem utalták azokat, hanem a tudományos megismerésen kívülre száműzték. Hayek indult el egy másik úton, amikor a szereplők viselkedését, várakozásainak alakulását a tanulási folyamattal hozta összefüggésbe, ami a mai kortárs szakirodalomban központi szerepet kap.

\section{A várakozások modellezése}

\section{Extrapolatív várakozások}

A várakozások első formalizált modellje Keynes Általános elméletéhez kapcsolódva jelent meg Lloyd A. Metzler tanulmányában. A gazdasági cikluselméletek feltételezik, hogy a gazdaság egyensúlyi állapot felé tart, ezért Metzler [1941] szerint a dinamikus sorozatok annyiban relevánsak ezen elméletek számára, amennyiben jelzik, hogy a gazdaság hogyan mozdul egyik egyensúlyi állapotból a másikba. Ha a kiigazítási periódus viszonylag rövid, akkor a dinamikus rendszer figyelmen kívül hagyható, és az időbeli mozgás egyszerủen a statikus rendszer parametrikus változásának tulajdonítható. Metzler a komparatív statika és a gazdasági dinamika kapcsolatát a beruházási multiplikátorral összefüggésben kívánta megmutatni. A beruházás és jövedelem kapcsolatának megfogalmazásában ugyanis Keynesnél sem derült ki, hogy a rendszer hogyan és miért jut el az egyik egyensúlyi állapotból a másikba. Metzler a stockholmi iskola dinamikussorozat-elemzésére is építve abból indult ki, hogy a gazdasági szereplök a termelésre vonatkozó döntéseiket az előző időszak eladására alapozzák, valamint a készleteknek is van egy normálszintjük, amit fenn kívánnak tartani. A beruházási javak termelését konstansnak tekintette, és feltételezte, hogy a fogyasztási javak termelését az elöző időszak nemzeti jövedelemének a fogyasztási határhajlandósággal meghatározott hányadához igazítják. A $t$-edik periódusra termelt készlet megegyezik a $t$-1-edik időszak tényleges és anticipált eladása közötti különbözettel. Az elözö, $t$-1-edik időszak anticipált eladását viszont $t$-2-edik időszak tényleges eladására alapozzák.

$y(t)=u(t)+v_{0}$

$u(t)=\beta y(t-1)$

$s(t)=\beta y(t-1)-\beta y(t-2)$, 
ahol $y$ a teljes megtermelt jövedelem, $u$ az eladásra szánt fogyasztási cikkek termelése, $s$ a készlet, $v_{0}$ a nettó beruházás, $\beta$ a fogyasztási határhajlandóság.

Metzler az üzleti várakozásokat egy $\eta$ koefficiens segítségével vonta be a modellbe, amit saját maga hasonlított össze Hicks várakozási rugalmasságával. A jelen időszakra vonatkozó döntés annak a várakozásnak a korrekciójával alakul ki, amelyben az előző két ciklus eladásait figyelembe veszik:

$u(t)=\beta y(t-1)+\eta[\beta y(t-1)-\beta y(t-2)]$.

Metzler modelljét kiterjesztette a készletváltozásra is, de témánk szempontjából elegendő eddig követnünk, mert az 1950-1960-as években nem ez, hanem az adaptív várakozások elmélete került az érdeklődés középpontjába.

\section{Adaptív várakozások}

Mind az adaptív, mind a racionális várakozások gondolatának forrásvidékén megtaláljuk a pókhálótételt. Nerlove [1958] és Muth [1961] egyaránt hivatkoztak rá klasszikussá vált tanulmányaikban, ezért nekünk is innen kell indulnunk. A pókhálóelmélet eredete az 1930-as évekre nyúlik vissza. Henry Schultz, Jan Tinbergen és Umberto Ricci egymástól függetlenül jelentetett meg Berlinben és Bécsben egy-egy tanulmányt 1930-ban, amelyek hasonló mondanivalóját azután Káldor Miklós nevezte el 1934ben pókhálóelméletnek (Kaldor [1934]). A termelés és az árak igazodásának olyan mechanizmusát írták le, ami megmagyarázza a ciklusok állandó újragenerálódását. Hivatkozva a három elözményre, Mordecai Ezekiel fogalmazta meg általánosabban a pókhálóelméletet. Ezekiel [1938] azt mutatta meg, hogy statikus feltételek mellett sem szükségszerü, hogy ha az árak és a termelés kimozdulnak az egyensúlyi állapotból, visszatérjenek oda. Az elmélet alkalmazható, ha a termelés teljesen a termelők árakra adott válaszaitól függ, amely árakra viszont nincs befolyásuk. A jövőre vonatkozó termelési döntés azon alapul, hogy a jelenlegi árak fennmaradnak, és a termelt menynyiség egy termelési perióduson belül nem változtatható meg. Tehát ha a termelők nem egyensúlyi árakhoz igazítják a termelésüket, akkor a következő időszakban sem az egyensúlyi mennyiséget viszik a piacra. A kereslet és a kínálat egymáshoz viszonyított rugalmasságától függően lehet folyamatos a fluktuáció, illetve közeledhet és távolodhat az egyensúlyi ponttól. Az elmélet tehát egy roppant egyszerü, naivnak is nevezett várakozásokra épült, amit leginkább mezőgazdasági piacokra alkalmaztak. Ezekiel például burgonyapiaci adatokkal illusztrálta elméletét.

Marc Nerlove, Phillipe Cagan két évvel korábbi modelljére hivatkozva, ${ }^{3}$ annak variánsaként, fejlesztette ki adaptívnak nevezett várakozási elméletét (Nerlove [1958]), amely már Ezekielénél életszerübb feltételezést fogalmazott meg, és ezt összekapcsolta a pókhálóelmélettel. Nerlove különbséget tett a jövőbeli árakra vonatkozó

\footnotetext{
${ }^{3}$ Cagan a hiperinfláció monetáris dinamikáját vizsgálva fogalmazta meg, hogy az árváltozások várható rátáját periódusonként annak arányában vizsgálják felül, hogy milyen a különbség az árváltozások tényleges és várt rátája között (Cagan [1956] 37. o.).
} 
várakozások autonóm és indukált komponensei között, csak az utóbbit tekintve a tudományos elemzés tárgyának. Az indukált várakozások az árak múltbeli mozgásából származnak, azonban a gazdasági szereplők a naiv várakozásokkal szemben tanulnak a múltbeli tévedésekből, és ezzel korrigálják a jelenre vonatkozó várakozásaikat:

$P_{t}^{*}-P_{t-1}^{*}=\beta\left[P_{t-1}-P_{t-1}^{*}\right], \quad 0<\beta \leq 1$,

ahol $P_{t}^{*}$ a $t$-edik időszakban várt ár, $P_{t-1}$ a tényleges ár a $t$-1-edik időszakban és $\beta$ az arányossági állandó, a várakozási koefficiens (Nerlove ([1958] 231. o.).

$\mathrm{Az}$ adaptív várakozásokat a makroökonómia számos területén felhasználták, az egyik legnevezetesebb alkalmazása Milton Friedman nevéhez füződik, amikor is az infláció és a munkanélküliség kapcsolatát a Phillips-görbe átértelmezésén keresztül magyarázta (Friedman [1986a], [1986b]). Ezek a jól ismert elemzések kiléptek a gazdasági ciklusok szokásos kereteiből, és a gazdasági élet hullámzását a monetáris politikához kapcsolták hozzá, azaz a várakozásokat összekötötték a gazdaságpolitikával is.

\section{A racionális várakozásoktól a heterogén várakozások felé}

Az adaptív várakozások megközelítésével már Muth [1961] is elégedetlen volt, amely bevezette a racionális várakozások fogalmát, és az új klasszikus makroökonómia „ősforrása” lett. Miután egy jelenleg is meghatározó irányzatról van szó, és az iskolának könyvtárnyi irodalma van (vö. Galbács [2012]), a következőkben csak azokról a gondolatokról lesz szó, amelyeket az iskola kereteit meghatározó tanulmányok témánk szempontjából felvetettek.

Muth alapproblémája abból indult ki, hogy a gazdaság ciklikusságát magyarázó elméletek megközelítése korlátozott, mert éppen a várakozások alakulásának a módját nem tárják fel, ami nélkül a jövőbeli alakulásukra sem lehet előrejelzéseket adni. A racionális várakozások hipotézisét egy egyszerü eseten vezette le, egy nem raktározható, fix termelési idejü termék elszigetelt piacán. Arra a jól ismert végeredményre jutott, hogy a vállalatok aggregált várakozásai megegyeznek a gazdaságelmélet elörejelzéseivel, hiszen ha az elmélet előrejelzései jobbak lennének, mint a vállalatokéi, akkor a „bennfentesek” profitálnának a tudásukból (Muth [1961] 318. o.). Muth meglepőnek tartotta, hogy a racionalitás feltételezését éppen a várakozásoknál nem vezették be, hiszen a vállalkozói viselkedés minden más megközelítésében ezt alkalmazzák. Szerinte a racionalitásra alapozott módszerekkel a szisztematikus torzításokat, hiányos vagy helytelen információkat is lehet kezelni. A pókhálóelméletet több tanulmány nem tudta empirikusan igazolni, Muth ezekre hivatkozva állította, hogy az extrapolatív és az adaptív várakozásoknál jobb magyarázatot lehet adni a racionális várakozások feltételezésével.

Muth hipotézise az 1970-es évektől lett az új klasszikus makroökonómia központi tézise. Robert E. Lucas Jr. eszközárakról írt tanulmányában világossá tette, hogy Muth nagyon sajátosan oldotta meg a célkitüzését, vagyis azt, ahogy a várakozások formálódásának módját megmagyarázza. Lucas [1978] ezt a hipotézist a haszonmaximalizálás 
feltételezéséhez hasonlította, amely nem írja le, hogy a gazdasági szereplök hogyan tanulnak, dolgoznak fel információkat és így tovább. Ez inkább egy tulajdonság, amit a nem specifikált tanulási és alkalmazkodási folyamatok következményein keresztül lehet megragadni (1437. o.). Utalt arra is, hogy a racionális várakozások egyensúlyai egy fokozatos tapasztalatszerzésre alapozott, Bayes-tanulás eredményei. Később Lucas [1986] újra megerősítette, hogy a racionális várakozások és az adaptív viselkedés feltételezése - amit a kísérleti pszichológia hagyományosan használ - nem állnak egymással ellentétben, inkább kiegészítik egymást. Elismerte, hogy a közgazdaságtan felületesen szemléli az egyéni és társadalmi viselkedést (példaként említette, hogy az inflációs rátákat összehasonlító diagramon is egy-egy országot megtestesítő pont mögött kultúrák, politikai rendszerek sokfélesége, egyedi személyiségek milliói állnak). Szerinte azonban ez a felületesség adja a közgazdaságtan erejét, mert anélkül képes elöre jelezni az emberek viselkedését, hogy ismerné az összetételüket és az életüket.

A racionális várakozások makroökonómiai alkalmazásának közismerten súlyos következményei lettek a gazdaságpolitika mozgásterére, pontosabban ennek elméleti megítélésére nézve. A legfontosabb állításokat Thomas J. Sargent és Neil Wallace egy 1976-os tanulmányukban összegezték. Szerintük egy gazdasági modelltől megkövetelhető, hogy összhangban legyen a közgazdaságtan elméleti magjával, azaz a gazdasági optimalizáló viselkedéssel egy általános egyensúlyi kereten belül, ugyanakkor ne mondjon ellent a megfigyeléseknek. A racionális várakozás összeegyeztethető ezekkel a feltételekkel, ráadásul ökonometriailag azonosítható, szemben a megelőző elméletek várakozási paramétereivel. Összhangban a közgazdaságtan szokásos feltételezésével, a racionális várakozások elmélete ugyan nem zárja ki, hogy ne fordulna elő irracionális és neurotikus viselkedés, de rendszerszinten feltételezi az önérdekkövető magatartást. Ahhoz, hogy anticiklikus gazdaságpolitikát lehessen követni, szisztematikusan el kellene térni a racionális viselkedéstől, amelyet a monetáris hatóságoknak valahogyan ismernie és elöre látni kellene (Sargent-Wallace [1976]).

Összességében az újklasszikus makroökonómia konzekvensen beépített egy olyan fogalmat a neoklasszikus föáram keretei közé, amellyel az elődök mintegy fél évszázadon keresztül küzdöttek, és ezzel a várakozások elmélete is osztozik mindazokban az előnyökben és korlátokban, amelyek a neoklasszikus paradigmát jellemzik. Ennek megfelelően a kritikák aszerint ágaznak ketté, hogy a paradigmán kívül vagy belül keresik a megoldást.

A posztkeynesisták például Keyneshez visszanyúlva bírálják a várakozások formalizálását, mert szerintük ezekkel az egyszerüsítésekkel nem ragadhatók meg azok (a részletes kritikát lásd Bélyácz [2013]).

A másik irány a neoklasszikus alapok megtartása mellett az erősen leegyszerüsítő feltételezések közelítése a valósághoz. Cars Hommes arra mutatott rá, hogy a racionális várakozások forradalma a közgazdaságtanban akkor ment végbe, amikor a közgazdászok körében nem voltak ismertek a természettudományokban és matematikában kifejlődött káoszelmélet eredményei (Hommes [2013]). A 2008-as globális válság tapasztalata további ösztönzést adott, hogy továbblépjünk abból a modellből, amely a külső sokkok hiánya esetében kiiktatta a szisztematikus hibák lehetőségét. A múltbeli megközelítések - a pókhálóelmélettől kezdve a hagyományos elméletig - számos 
elemét megtartva, Hommes arra tett javaslatot, hogy a várakozásokat heterogénnek tekintve, a korlátozott racionalitás 1950-es évek óta ismerős gondolatát ismét elővegyük, és egy komplex, nemlineáris modellbe építve kezeljük a várakozások hatását a gazdasági folyamatokra. A korlátozott racionalitást például úgy értelmezte, hogy a gazdasági szereplők egyszerü, intuitív döntési szabályokat használnak, amelyeket evolúciós szelekció és tanulás alapján változtatnak, és szerinte ez a modell empirikusan igazolható mind mikro-, mind makroszinten. Ezt az empirikus igazolást az eszközárazás modelljén végezte el. Szimbolikusnak tekinthetjük, hogy a közgazdasági elmélet fejlődését a racionálistól a heterogénnek tekintett várakozások irányába Sargent „szentesítette” Hommes könyvéhez írt ajánlásával.

\section{Következtetések}

Áttekintve a várakozások szerepét a közgazdasági gondolkodás történetében, egy hoszszú fejlődési utat lehetett rekonstruálni. A fentieken kívül még számos szerző számos hozzájárulása feldolgozható lenne, de a jelen tanulmány célja csupán egy történeti ív felvázolása, amellyel megválaszolható a bevezetőben feltett kérdés.

A várakozások kezdeti figyelmen kívül hagyása után a valóság problémái kikényszerítették, hogy befurakodjanak a statikus egyensúlyi modellek világába. A várakozásokat alakító okok magyarázatánál azonban a 1930-as évek dinamikus elemzéssel kísérletező közgazdászai rendre zavarba jöttek, mert az okokat részben valamiképpen tapasztalatokra vezették vissza, részben tudományosan nem magyarázható, gazdaságon kívüli tényezőkre. A 1940-es évektől erősödő formalizálás ugyanezt a meghatározhatatlanságot egy koefficiens beiktatásával próbálta megoldani. Az újklasszikus makroökonómia a racionális várakozások hipotézisével képes volt a várakozásokat beilleszteni a fỏáramú közgazdaságtan keretei közé azáltal, hogy a racionális várakozások kialakításának képességét éppúgy egy deduktív modell elemévé, posztulátumává tette, mint a haszonmaximalizálást vagy a preferenciák konzekvens elrendezését. A várakozási hibákat a reprezentatív szereplők feltételezése tüntette el, a várakozások alakulásának konkrét vizsgálatát az adaptív tanulás váltotta ki. Az újabb modellekben a várakozások heterogenitásának és a korlátozott racionalitásnak a feltételezése megszabadít a legerősebb egyszerüsítésektől, miközben az adaptív tanulás kulcsszerepe megmarad.

A fentiek alapján azt a következtetést lehet levonni, hogy a közgazdaságtan egyfelöl számos területen jelentős magyarázó erővel rendelkező modelleket alkotott, másfelől viszont a bevezetésben feltett, gazdaságpolitikai szempontból nagyon is releváns problémák feltárásában a foáramú közgazdaságtan nem tartja magát illetékesnek. A várakozások formálódását mint társadalomba ágyazott folyamatot sohasem vonta vizsgálatai körébe. A legújabb, leginkább árnyalt megközelítések is csak addig jutnak el, hogy a racionális viselkedéstől eltérő magatartást mint átmeneti - tanulási folyamattal kiküszöbölhető - jelenséget fogják fel. Azt a helyzetet, amikor a várakozásokat közgazdasági szempontból nem racionális, de nem is átmeneti, nem is irracionális - azaz tudományosan nem vizsgálható - hatások formálják, hanem másfajta, szociológiailag, politológiailag jól azonosítható, tartós hatások, a föáramú közgazdaságtan nem veszi figyelembe. 
Az utóbbi esetre a kortárs szakirodalomban csak egyetlen egy olyan példát találtam, Bruno Amable politikai gazdaságtani munkáját, amely a tartós gazdasági problémák magyarázatában felfigyel a várakozások szerepére. Amable [2014] empirikus vizsgálatok alapján elemezte, hogy Franciaországban mind a jobb-, mind a baloldali kormányok 1978 óta olyan gazdasági modernizációs politikát folytatnak, amely ellentmond az őket támogató társadalmi bázis gazdaságpolitikai várakozásainak. Ez a feszültség egyfelől lanyha gazdasági növekedéshez, másfelől a hivatalban lévő kormányok folyamatos bukásához, a választói passzivitás erösödéséhez, Amable megfogalmazásában politikai krízishez vezetett.

Mindezeket úgy összegezhetjük, hogy a várakozások tanulmányozása még sok lehetőséget tartogat mind a szűkebben értelmezett, föáramú közgazdaságtan, mind a gazdaság társadalomba ágyazottságát szem előtt tartó politikai gazdaságtan számára.

\section{Hivatkozások}

AmabLE, B. [2014]: The unsolved contradictions of the modernists. Economic policy expectations and political crisis in France 1978-2012. Documents de travail du Centre d'Economie de la Sorbonne, Párizs, https://halshs.archives-ouvertes.fr/halshs-00973926/document.

Arisztotelész [1984]: Politika. Gondolat Kiadó, Budapest.

BÉLYÁCz IváN [2013]: Várakozások, bizonytalanság, valószínűség. Közgazdasági Szemle, 60. évf. 7-8. sz. 749-780. o.

Cagan, P. [1956]: The Monetary Dynamics of Hyper-Inflation. Megjelent: Friedman, M. (szerk.): Studies in the Quantity Theory of Money. University of Chicago Press, Chicago, 25-117. o.

Collard, D. [1996:] Pigou and Modern Business Cycle Theory. The Economic Journal, Vol. 106. No. 437. 912-924. o. http://dx.doi.org/10.2307/2235364.

Ezekiel, M. [1938]: The Cobweb Theorem. Quarterly Journal of Economics, Vol. 52. No. 2. 255-280. o.

Farkas BeÁta [2016]: Models of Capitalism in the European Union. Post-crisis Perspectives. Palgrave Macmillan, Basingstoke-New York.

Festré, A. [2006] Knut Wicksell and Ludwig von Mises on Money, Interest and Price Dynamics. Journal of the History of Economic Thought, Vol. 28. No. 3. 333-357. o. http://dx.doi. org/10.1080/10427710600857856.

FisheR, I. [1907]: The Rate of Interest, its Nature, Determination and Relation to Economic Phenomena. Macmillan, New York.

FisheR, I. [1930]: The Theory of Interest, as determined by Impatience to Spend Income and Opportunity to Invest it. Macmillan, New York.

Friedman, M. [1986a]: A monetáris politika szerepe. Fordította: Király Júlia. Megjelent Friedman, M.: Infláció, munkanélküliség, monetarizmus. Közgazdasági és Jogi Könyvkiadó, Budapest, 221-239. o.

Friedman, M. [1986b]: Infláció és munkanélküliség. Fordította: Király Júlia. Megjelent Friedman, M.: Infláció, munkanélküliség, monetarizmus. Közgazdasági és Jogi Könyvkiadó, Budapest, 240-263. o..

GalbÁcs Péter [2012]: Aktív szabályozás vagy gazdaságpolitikai nihilizmus? Akadémiai Kiadó, Budapest. 
Hayek, von F. A. [1937]: Economics and Knowledge. Economica, New Series, Vol. 4. No. 13. 33-54. o.

Hicks, J. [1965]: Capital and Growth. Oxford University Press, Oxford.

Hicks, J. [1978]: Érték és tőke. A keynesi gazdaságtan válsága. Közgazdasági és Jogi Könyvkiadó, Budapest.

Hommes, C. [2013]: Behavioral Rationality and Heterogeneous Expectations in Complex Economic Systems. Cambridge University Press, Cambridge. http://dx.doi.org/10.1017/ CBO9781139094276.

KALDOR, N. [1934]: A Classificatory Note on the Determination of Equilibrium. Review of Economic Studies, Vol. 1. 122-136. o.

KeYnes, J. M. [1965]: A foglalkoztatás, a kamat és a pénz általános elmélet. Közgazdasági és Jogi Könyvkiadó, Budapest.

Lindahl, E. [1970]: Studies in the Theory of Money and Capital. Augustus M. Kelley Publishers, New York

Lucas, R. E. JR. [1978]: Asset Prices in an Exchange. Economy Econometrica, Vol. 46. No. 6. 1429-1445. o.

LuCAs, R. E. JR. [1986]: Adaptive Behavior and Economic Theory. Journal of Business, Vol. 59. No. 4. 401-426. o.

Madarász Aladár [2000]: Knut Wicksell. Megjelent: Bekker Zsuzsa (szerk.): Alapművek, alapirányzatok. Aula Kiadó, Budapest, 428-429. o.

Marshall, A. [1997]: Principles of Economics. Prometheus Books, New York.

Meacci, F. [2012]: On Adam Smith's Ambiguities on Value and Wealth. History of Political Economy, Vol. 44. No. 4. 663-689. o. http://dx.doi.org/10.1215/00182702-1811379.

Metzler, L. A. [1941]: The Nature and Stability of Inventory Cycles. Review of Economics and Statistics, Vol. 23. No. 3. 113-129. o.

MiLL, J. S. [1874-1875]: A nemzetgazdaságtan alapelvei. Légrády Testvérek, Budapest.

Muth, J. F. [1961]: Rational Expectations and the Theory of Price Movements. Econometrica, Vol. 29. No. 3. 315-335. o.

Nerlove, M. [1958]: Adaptive Expectations and Cobweb Phenomena. The Quarterly Journal of Economics. Vol. 72. No. 2. 227-240. o.

Pigou, A. C [1932]: The Economics of Welfare. 4. kiadás, Macmillan, London.

RiCARDO, D. [1991]: A politikai gazdaságtan és az adózás alapelvei. Közgazdasági és Jogi Könyvkiadó, Budapest.

RICARDO, D. [1969]: Megjegyzések Malthus „A politikai gazdaságtan elvei” című művéhez. Akadémiai Kiadó, Budapest.

Sargent, T. J.-Wallace, T. [1976]: Rational Expectations and the Theory of Economic Policy. Journal of Monetary Economics, Vol. 2. No. 2. 169-183. o.

Sмith, A. [1977]: Az erkölcsi érzelmek elmélete. Fordította: Fehér Ferenc. Megjelent: Márkus György (szerk.): Brit moralisták a XVIII. században. Gondolat Kiadó, Budapest, 1977, 423-553. o.

SMith, A. [1940]: Vizsgálódás a nemzetek jólétének természetéről és okairól. 1-2. kötet. Fordította: Éber Ernő. Magyar Közgazdasági Társaság, Budapest.

Thornton, H. [1965]: An Enquiry into the Nature and Effects of the Paper Credit of Great Britain. A. M. Kelly, New York.

WiCKselL, K. [1936]: Interest and Prices. Macmillan and Co., London. 